Piotr KORUBA

Tomasz BORATYŃSKI ${ }^{2}$

Piotr JUREWICZ ${ }^{3}$

Gustaw KOENIG ${ }^{4}$

Michał SZAROLETA ${ }^{5}$

Jacek REINER ${ }^{6}$

Edward CHLEBUS ${ }^{7}$

Adam DWORAK ${ }^{8}$

\title{
PROJEKTOWANIE I ANALIZA ZASTOSOWAŃ TECHNOLOGII NAPAWANIA LASEROWEGO DLA BRANŻY LOTNICZEJ
}

\begin{abstract}
Technologia napawania laserowego polega na wykorzystaniu wiązki laserowej celem precyzyjnego nałożenia warstwy materiału o podwyższonych właściwościach na podłoże. Szczególne zainteresowanie budzi ona w branży lotniczej. Odpowiednie przygotowanie procesu wiąże się z wykonaniem testów symulacyjnych z wykorzystaniem modeli przepływu dwufazowego oraz interakcji wiązki laserowej z materiałem. Następnie zostają wyznaczone ścieżki ruchu głowicy przy użyciu dedykowanych narzędzi CAD/CAM. W ramach analizy technologii napawania laserowego dla zastosowań branży lotniczej przedstawiono nakładanie powłok funkcjonalnych, będących alternatywą dla chromu elektrolitycznego. Przeanalizowano również metodę regeneracji wierzchołka łopatki turbiny silnika odrzutowego. Zaprezentowano też możliwości obróbki hybrydowej w wytwarzaniu przyrostowym tytanowych komponentów lotniczych oraz metodę monitorowania temperatury celem jakościowej kontroli procesu.
\end{abstract}

Słowa kluczowe: komputerowe wspomaganie procesu, symulacje multifizyczne, powłoki funkcjonalne, regeneracja łopatek, napawanie hybrydowe

\footnotetext{
${ }^{1}$ Autor do korespondencji/corresponding author: Piotr Koruba, Politechnika Wrocławska, ul. Łukasiewicza 5, 50-371 Wrocław, tel.: 71 3204635, e-mail: piotr.koruba@pwr.edu.pl

2 Tomasz Boratyński, Politechnika Wrocławska, e-mail: tomasz.boratynski@pwr.edu.pl

${ }^{3}$ Piotr Jurewicz, Politechnika Wrocławska, e-mail: piotr.jurewicz@ pwr.edu.pl

${ }^{4}$ Gustaw Koenig, Politechnika Wrocławska, e-mail: gustaw.koenig@pwr.edu.pl

${ }^{5}$ Michał Szaroleta, Politechnika Wrocławska, e-mail: michał.szaroleta@pwr.edu.pl

${ }^{6}$ Jacek Reiner, Politechnika Wrocławska, e-mail: jacek.reiner@pwr.edu.pl

${ }^{7}$ Edward Chlebus, Politechnika Wrocławska, e-mail: edward.chlebus@pwr.edu.pl

8 Adam Dworak, PZL Mielec, e-mail: adam.dworak@1mco.com
} 


\section{Wprowadzenie}

Technologia napawania laserowego stanowi wciąż rozwijający się obszar laserowej obróbki powierzchniowej oraz objętościowej. W procesie tym wiązka laserowa przetapia cząstki metalowego proszku lub drut oraz cienką warstwę materiału rodzimego w celu nałożenia i związania warstwy materiału napawanego [1]. Tym sposobem naniesione mogą zostać różnorodne materiały metalowe, węgliki, kompozyty i ceramiki $[2,3]$. Ze względu na niewielkie wtopienie w materiał podłoża możliwe jest otrzymanie znacznie wyższych właściwości warstwy napawanej niż technologiami konwencjonalnymi $[1,3,4]$.

Ze względu na aplikację procesu napawania laserowego wyróżnia się nakładanie powłok funkcjonalnych, naprawę i regenerację zużytych części maszyn oraz wytwarzanie przyrostowe na podstawie cyfrowego modelu CAD [1,3]. Wszystkie $\mathrm{z}$ wymienionych form zastosowania technologii są wykorzystywane w branży lotniczej, gdzie kluczowym aspektem jest uzyskanie wysokich właściwości mechanicznych przy minimalizacji ciężaru komponentu. Przyrostowy charakter technologii napawania laserowego jest wykorzystywany głównie do addytywnego wytwarzania części. Ze względu na specyfikę procesu najbardziej opłacalne jest jego wykorzystanie w produkcji jednostkowej lub małoseryjnej, takiej jaka występuje w branży lotniczej. Szczególne zainteresowanie wzbudzają dwa podejścia: połączenie procesu napawania oraz obróbki skrawaniem w ramach obróbki hybrydowej oraz zastosowanie monitorowania sygnałów resztkowych z procesu, celem sterowania parametrami procesu, takimi jak moc lasera [3]. Oba podejścia umożliwiają zapewnienie jakości otrzymanych komponentów czy to przez cykliczne wyrównanie powierzchni z użyciem frezu, czy przez adaptacyjne sterowanie parametrami procesu podczas jego realizacji.

Interdyscyplinarność technologii napawania laserowego przejawia się w liczbie i różnorodności zmiennych wejściowych do procesu [4, 5]. Dotyczą one zarówno parametrów źródła laserowego, metody podawania materiału dodatkowego, układu manipulacji, jak i właściwości podłoża oraz materiału dodatkowego [6]. Taka liczba zmiennych procesów pociąga za sobą potrzebę minimalizacji prób eksperymentalnych, w czym pomocne jest opracowanie symulacyjnych modeli procesu [5]. Obliczenia symulacyjne stanowią zatem wstępne oszacowanie parametrów procesu, wykorzystywanych w dalszym etapie badań. W przypadku opracowania technologii napawania laserowego niezbędne jest również zastosowanie oprogramowania do generowania ścieżek narzędzia, którym jest głowica laserowa (w przypadku obróbki hybrydowej są to narzędzia skrawające).

W ramach analizy technologii napawania laserowego do zastosowań branży lotniczej przedstawiono przykładowe realizacje procesu dla każdej z wymienionych aplikacji, ze szczególnym uwzględnieniem etapów projektowania technologii. Zaprezentowano również niezbędne przy wytworzeniu wysokiej jakości elementów czynności przygotowawcze, takie jak symulacje oraz generowanie ścieżek głowicy laserowej, a także metody jakościowej kontroli procesu. 


\section{Komputerowe wspomaganie projektowania technologii}

Napawanie laserowe jest procesem multifizycznym, którego parametry są wielkościami związanymi z zastosowanym laserem, materiałami podstawowym oraz dodatkowym oraz operacjami pomocniczymi, takimi jak obróbka cieplna [4]. Podczas procesu zachodzą zjawiska fizyczne związane z wymianą ciepła, przepływem gazów, interakcją wiązki laserowej z materią, mikrometalurgią proszków oraz spawalnością $[4,5]$.

Duża liczba parametrów wpływających na proces czyni kosztownym opracowanie technologii jedynie na podstawie dużej liczby prób eksperymentalnych. Istotną częścią prac badawczych związanych z technologią napawania laserowego jest zatem opracowanie modelu procesu na podstawie eksperymentu (tzw. model empiryczno-statystyczny) oraz symulacji zjawisk fizycznych (tzw. model fizyczny) [5]. Modele eksperymentalne (np. modele regresyjne, metoda odpowiedzi powierzchni) przedstawiają korelacje między wytypowanymi parametrami wejściowymi procesu oraz wybranymi wielkościami wyjściowymi, tj. najczęściej właściwościami napawanych struktur, przy czym wymagają ponownego opracowania przy jakichkolwiek zmianach wyposażenia stanowiska lub otoczenia.

Drugie z rozwiązań umożliwia zarówno kompleksową, jak i szczegółową budowę modelu fragmentu procesu, co pozwala na dokładniejsze zrozumienie zjawisk w nim występujących. Jako przykłady można podać model dwufazowy dyszy do napawania oraz symulację interakcji wiązki laserowej z materiałem podłoża z uwzględnieniem przemian fazowych (rys. 1.).

Zastosowanie wspomnianych modeli znacznie skraca czas opracowania technologii napawania laserowego przez możliwość wstępnego doboru parametrów procesu na podstawie badań symulacyjnych. Dodatkowo możliwa jest predykcja właściwości napawanej struktury oraz głębsze zrozumienie zjawisk zachodzących w procesie.

W przypadku technologii napawania laserowego mogą być również stosowane programy wspomagające projektowanie geometrii przedmiotów i przebiegu obróbki, tj. zintegrowane oprogramowanie CAD/CAM. Przy wytwarzaniu generatywnym udział komputera na etapie planowania procesu staje się już niezbędny, aby przeliczyć wczytany model geometryczny na zestaw cienkich i płaskich warstw, które wynikowo mają stanowić gotowy komponent. Przy odpowiednio dobranej strategii model obiektu zostanie podzielony na zestaw płaskich torów związanych z plamką lasera, które zostaną kolejno nadbudowane pojedynczo od dołu do góry [6].

Oprogramowanie DCAM pozwala na generowanie ścieżek w 5 osiach frezarki oraz w 8 osiach dla robota (rys. 2.). Możliwa jest symulacja uwzględniająca kinematykę maszyny oraz oprzyrządowanie. Po zaimportowaniu modelu 3D napawanego elementu należy zdefiniować parametry technologiczne dla ścieżki składającej się z wypełnienia oraz przejść konturowych. Specjalnie przygotowany postprocesor pozwala na generowanie programów sterujących ruchami frezarki 
lub robota oraz obsługą urządzeń automatyki przemysłowej. Włączanie i wyłączanie wiązki lasera, podajnika proszku, gazów technologicznych jest realizowane bezpośrednio z programu NC. Środowisko DCAM generuje ścieżki ruchu głowicy laserowej dla elementów objętościowych oraz powłok, przy czym możliwe jest napawanie powierzchni swobodnych, spiralnych oraz radialnych.

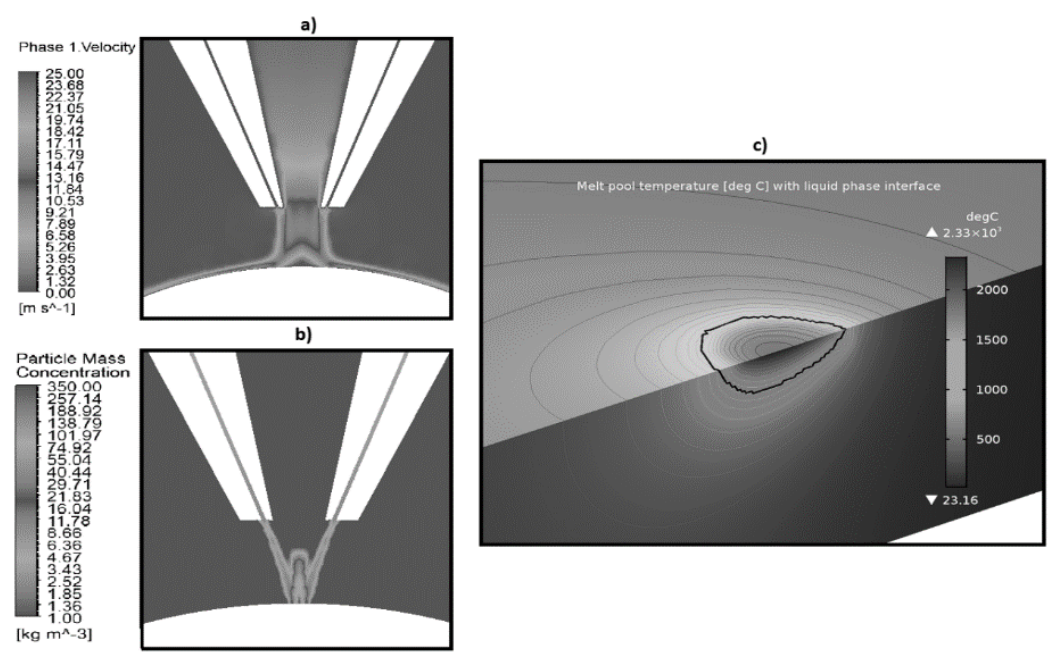

Rys. 1. Symulacje zjawisk w procesie napawania laserowego: a) prędkości gazu osłonowego, b) koncentracji proszku, c) interakcji wiązki laserowej z podłożem i utworzenia jeziorka (czarna linia)

Fig. 1. Simulations of laser cladding phenomena: a) shielding gas velocity, b) powder concentration, c) laser beam interaction with substrate and melt pool formation (black line)

a)

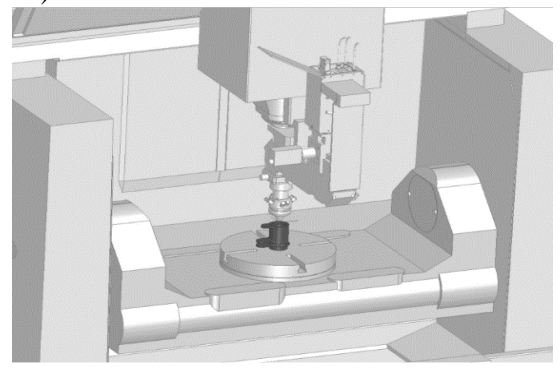

b)

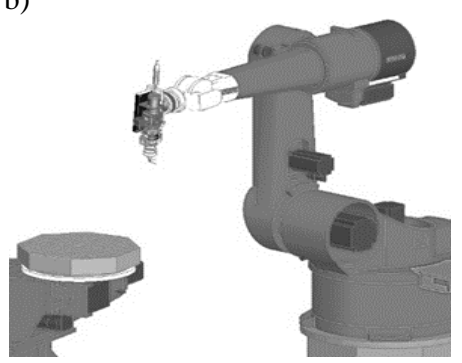

Rys. 2. Modele cyfrowe stanowisk do napawania laserowego: a) frezarka CNC Hermle C20U, b) robot przemysłowy Reis RV60-40

Fig. 2. Digital models of laser cladding stations: a) CNC milling machine Hermle C20U, b) robot Reis RV60-40 


\section{Kontrola procesu}

$\mathrm{Na}$ przebieg procesu napawania laserowego i geometrię otrzymywanych struktur wpływa wiele czynników, związanych głównie z parametrami procesu oraz materiału podstawowego. Czynniki te mogą się zmieniać w trakcie procesu, prowadząc do niepożądanych zmian w jego przebiegu i w efekcie do niezgodności geometrycznych.

Wspomniane problemy są szczególnie widoczne przy napawaniu elementów cienkościennych. Taki proces realizuje się przez naprzemienny ruch głowicy laserowej w dwóch kierunkach wzdłuż jednej osi, z odsuwaniem głowicy od materiału w punktach jej nawrotu. Zastosowanie stałych parametrów procesu prowadzi do niezgodności geometrycznych w postaci pogrubienia struktury w tych miejscach. Jednocześnie przy stałych parametrach nakładanie kolejnych warstw struktury powoduje kumulację ciepła, co skutkuje rozrostem jeziorka ciekłego metalu i w efekcie poszerzaniem struktury wraz ze wzrostem wysokości (rys. 3a).

Jednym ze sposobów kompensacji opisanych zjawisk jest rejestracja promieniowania podczerwonego [7], niosącego informację o temperaturze procesu, lub rejestracja promieniowania widzialnego [8], niosącego informację o geometrii jeziorka płynnego metalu. Na podstawie jednego lub obu wspomnianych sygnałów steruje się mocą lasera, tak aby zapewnić jego stały przebieg. Na podstawie badań potwierdzono, że zastosowanie takiego sterowania umożliwia znaczne ograniczenie niezgodności geometrycznych (rys. 3b).

a)

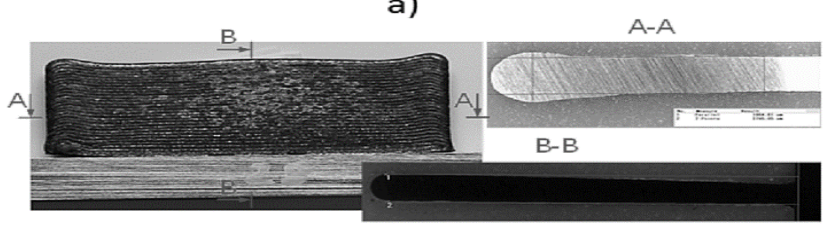

b)

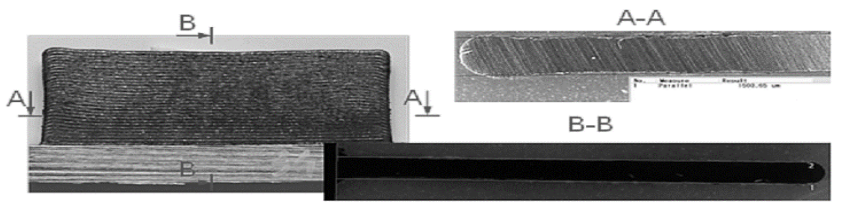

Rys. 3. Struktury cienkościenne uzyskane w procesie napawania laserowego: w pętli otwartej - bez sterowania (a), w pętli zamkniętej - ze sterowaniem (b)

Fig. 3. Thin-walled structures obtained in the laser deposition process: in open loop - without control (a), in closed loop - with control (b) 
Opracowane na Politechnice Wrocławskiej metody akwizycji sygnałów resztkowych oraz algorytmy ich przetwarzania zostały wyczerpująco przedstawione w monografii [3]. Inną kontrolę procesu można natomiast zastosować w przypadku wytwarzania hybrydowego (rys. 4.).

a)

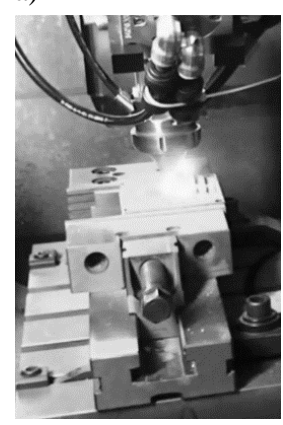

b)

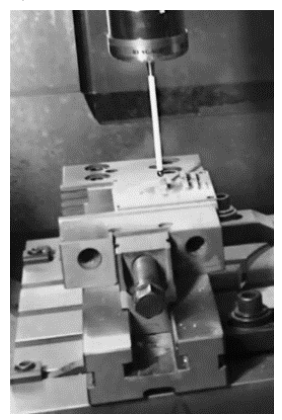

c)

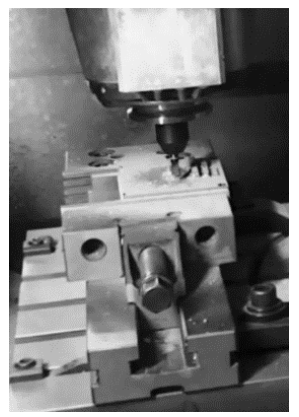

d)

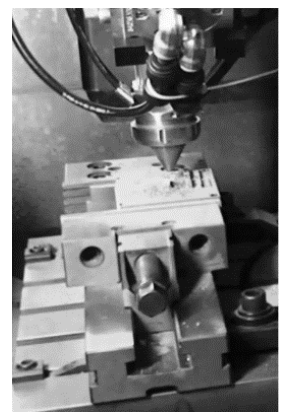

Rys. 4. Kontrola procesu przy wytwarzaniu hybrydowym - napawanie laserowe (a), kontrola przyrostu warstw (b), wyrównanie przyrostu warstw (c), korekta o +/- 0,2 mm aktualnej bazy

Fig. 4. Process control in the hybrid technology - laser cladding (a), layer increment control (b), equalization of layer increments (c), correction by $+/-0.2 \mathrm{~mm}$ of the current base

\section{Napawanie powłok funkcjonalnych}

Jednym z zastosowań technologii napawania laserowego jest nakładanie warstw funkcjonalnych na powierzchnię części maszyn. Umożliwia to wytworzenie powłoki o właściwościach lepszych niż materiału podłoża. Stosuje się to głównie celem poprawienia odporności na zużycie ścierne i korozję powierzchni $[6,9]$. W związku z wejściem w życie dyrektywy REACH odnośnie do stosowania związków chromu VI (rozporządzenie 301/2014) poszukiwane są rozwiązania mogące go zastąpić $[10,11]$. Obecnie powłoki z twardego chromu (EHC) są stosowane na powierzchniach o wysokich wymaganiach dotyczących odporności na zużycie ścierne i korozję. Wymaga się od nich również dobrej szczelności i niewielkiego wpływu na materiał podłoża.

Teoretycznie wszystkie te wymagania jest w stanie zapewnić powłoka nakładana za pomocą technologii napawania laserowego. Dzięki zastosowaniu wysoce skoncentrowanego źródła ciepła w postaci wiązki laserowej możliwe jest uzyskanie drobnoziarnistej struktury nakładanych warstw, co zapewnia wysoką twardość i w efekcie wysoką odporność na ścieranie. Zastosowanie wiązki laserowej umożliwia również uzyskanie wąskiej strefy wpływu ciepła. Technologia ta umożliwia również nakładanie stopów takich materiałów, jak: stal, nikiel, kobalt, chrom, tytan, aluminium czy miedź, w tym stopów o wysokiej odporności na korozję [6].

Celem opracowania procesu napawania laserowego oferującego powłokę mogącą zastąpić powłokę z twardego chromu przeprowadzono szeroko zakrojone 
badania składające się z kilku etapów, które zostały przedstawione na schemacie (rys. 5.).

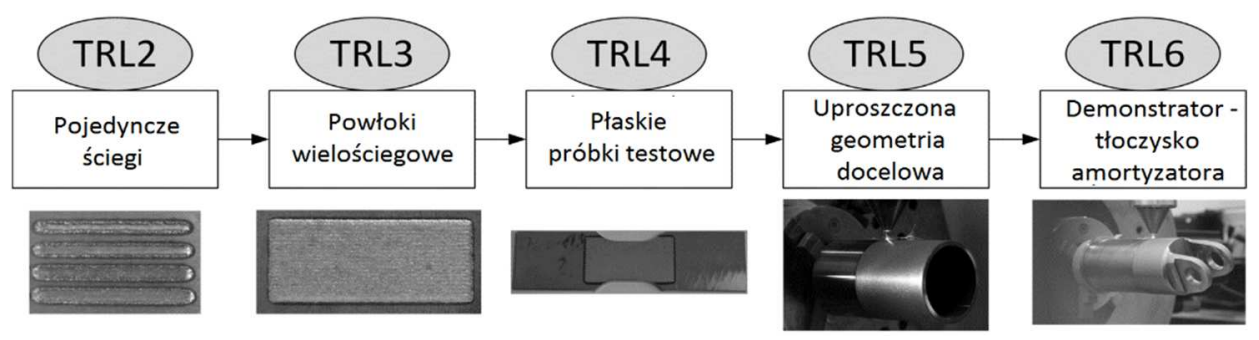

Rys. 5. Etapy pracy podczas opracowania powłoki napawanej laserowo jako alternatywy dla twardego chromu

Fig. 5. Workflow during development of laser deposited coating as an alternative for EHC

Głównymi zadaniami pierwszych dwóch etapów było wytypowanie materiału nakładanego oraz dobranie wstępnych parametrów procesu, umożliwiających uzyskanie powłoki wolnej od pęknięć, o niewielkim wpływie na materiał rodzimy i wysokiej twardości. W trzecim etapie, na podstawie tak dobranych parametrów, wykonano wiele próbek testowych, mających potwierdzić spełnienie przez powłokę postawionych wymagań co do odporności na korozję oraz zużycie ścierne, a także niewielki wpływ na podłoże. Na przygotowanych elementach zostały przeprowadzone m.in. takie próby, jak: statyczna próba rozciągania, odporność na zużycie ścierne luźnym ścierniwem czy odporność na korozję elektrolityczną. Wymienione próby potwierdziły spełnienie przez powłokę postawionych wymagań i niewielki wpływ na materiał podłoża. Kolejny, czwarty etap badań dotyczył dostosowania technologii do docelowej geometrii. Zaprojektowana została ścieżka narzędzia umożliwiająca nałożenie powłoki na powierzchni cylindrycznej. Została ona wykorzystana do wykonania demonstratora technologii, na którym będą wykonane testy eksploatacyjne, mające ostatecznie potwierdzić spełnianie przez powłokę postawionych wymagań.

\section{Regeneracja łopatki silnika odrzutowego}

Kolejnym powszechnym zastosowaniem technologii napawania laserowego jest naprawa drogich i skomplikowanych w wytwarzaniu części maszyn, wymagających uzyskania ponadprzeciętnych właściwości mechanicznych i wysokiej jakości metalurgicznej. Niewielki obszar oddziaływania źródła ciepła powoduje również, że napawanie laserowe jest użyteczne w naprawie elementów silnika odrzutowego, polegającej na nakładaniu na podłoże warstw z superstopów wrażliwych na nadmierne oddziaływanie wysokiej temperatury [11]. 
Jako przykład opisany został proces technologiczny naprawy wierzchołka łopatki turbiny z odlewniczego stopu niklu i kobaltu ŻS6U. Jako dodatkowy materiał proszkowy został użyty utwardzany wydzieleniowo nadstop niklu René 80. Wymagania geometryczne regenerowanej struktury wynikały z wymiarów nadbudowywanej ścianki, tj. wysokość ponad $2 \mathrm{~mm}$, szerokość $1 \mathrm{~mm}$, długość $25 \mathrm{~mm}$ (rys. 6.). Stop ŻS6U, wykorzystany w przypadku łopatki turbiny silnika, stanowi materiał trudno spawalny. Wynika to z podwyższonej zawartości Ti i Al zarówno w materiale podłoża, jak i dodatkowym, co skutkuje powstawaniem pęknięć starzeniowo-odkształceniowych. Defekty takie stanowią karby, które znacząco obniżają wytrzymałość zmęczeniową łopatki. Przy regeneracji łopatki turbiny silnika odrzutowego zastosowano dwie metody ograniczenia pęknięć: podgrzanie wstępne podłoża przy użyciu induktora oraz wykonanie warstw buforowych. Wykorzystanie dodatkowego źródła ciepła w postaci induktora ograniczyło liczbę występujących pęknięć, nie pozwoliło jednak na ich całkowitą eliminację.

Aby uzyskać symetryczne pokrycie podłoża, nałożono dwie warstwy buforowe ze stopu Inconel 718. Pozwoliło to na niemal całkowitą eliminację pęknięć, przy czym pojedyncze obserwowane defekty znajdowały się poza długością ścianki wierzchołka łopatki, tj. na strukturach podtrzymujących. Średnia uzyskana redukcja liczby pęknięć z zastosowaniem tej metody wynosiła ok. 96\% w stosunku do liczby pęknięć przy napawaniu ścianki bez warstw przejściowych [12].

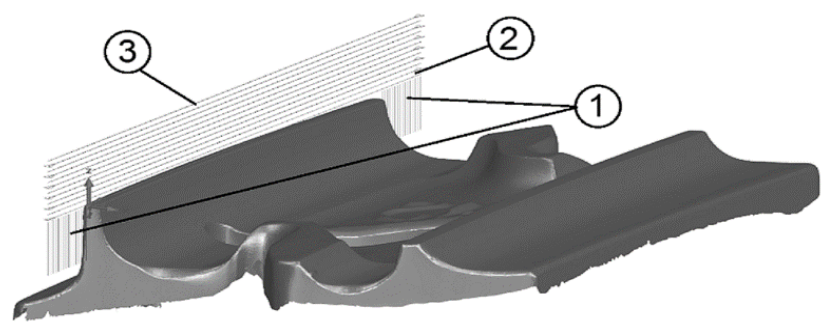

Rys. 6. Schemat kolejności napawania podczas naprawy końcówki łopatki turbiny (DCAM)

Fig. 6. Scheme of cladding sequence during turbine blade tip repair (DCAM)

Rekonstrukcja wierzchołka łopatki silnika odrzutowego została podzielona na 3 operacje (rys. 6.) zaprojektowane w środowisku SKM DCAM:

- budowa krótkich struktur podtrzymujących - 1,

- nałożenie 2 warstw buforowych ze stopu Inconel 718 - 2,

- napawanie 10 warstw z materiału Rene 80 - 3 . 


\section{Obróbka hybrydowa}

Części metalowe wytwarzane w procesach addytywnych charakteryzują się wysoką chropowatością i względnie niską dokładnością wymiarowo-kształtową. Przykładowo parametr chropowatości $R_{z}$ może wynosić od ok. 20 do $70 \mu \mathrm{m}$ $[13,14]$. Niespełnienie wymagań stawianych gotowym wyrobom stosowanym w przemyśle lotniczym oznacza, że w większości przypadków należy traktować te elementy jako półfabrykat wymagający dalszej obróbki. Wymusza to konieczność opracowania procesu produkcyjnego obejmującego co najmniej dwie operacje na odrębnych stanowiskach roboczych. Rozwiązanie takie jest jednak z wielu względów niekorzystne.

Obróbka hybrydowa oznacza połączenie dwóch procesów wytwórczych w jeden proces, w którym dzięki synergii uzyskuje się znaczne korzyści $[15,16]$. Mając na uwadze podaną definicję, opracowano rozwiązanie konstrukcyjne maszyny do obróbki hybrydowej. Rozwiązanie to, opisane w normie ASTM F3187-16, integruje wytwarzanie przyrostowe przez napawanie laserowe oraz obróbkę skrawaniem w jednej operacji podzielonej na wiele zabiegów.

$\mathrm{Na}$ Politechnice Wrocławskiej opracowano urządzenie składające się z 5-osiowego centrum frezarskiego Hermle C20U wyposażonego w głowicę laserową do napawania COAX 9. Maszyna ta została dodatkowo wyposażona w autorski układ automatycznego mocowania głowicy laserowej. Rozwiązanie to jest obecnie przedmiotem zgłoszenia patentowego. $Z$ wykorzystaniem opisanego stanowiska są prowadzone prace badawczo-rozwojowe, których celem jest poprawa ekonomiczności procesu produkcji dzięki zastosowaniu innowacyjnej technologii wytwarzania. Wykorzystanie do tego celu obrabiarki wieloosiowej umożliwia redukcję czasu trwania procesu technologicznego, przy obróbce wielostronnej i eliminacji czynności ustawczych (rys. 7.). Podczas wytwarzania komponentu samolotu przez napawanie proszku stopu tytanu Ti6Al4V osiągnięto objętościową wydajność wynoszącą ok. $45 \mathrm{~mm}^{3} / \mathrm{min} \mathrm{z}$ zastosowaniem włóknowego źródła laserowego o mocy nominalnej $200 \mathrm{~W}$ i dyszy do napawania precyzyjnego.

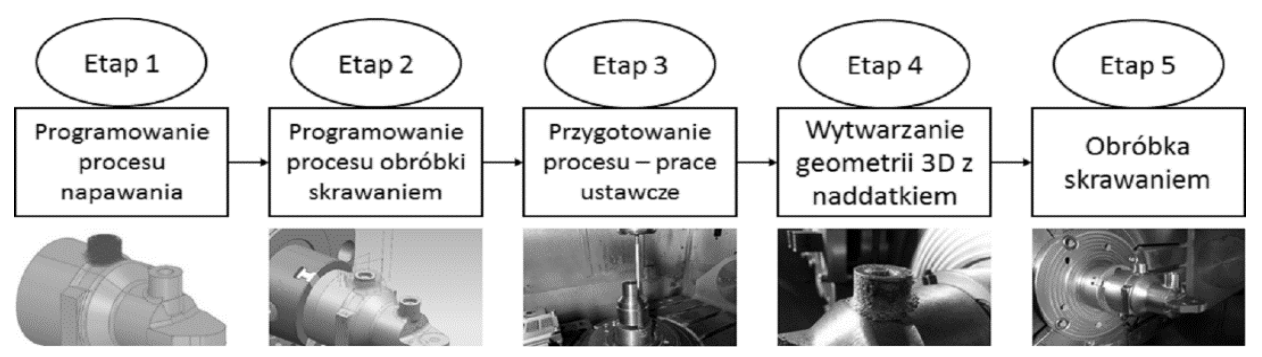

Rys. 7. Adaptacja technologii hybrydowej w wytwarzaniu części lotniczej

Fig. 7. Adaptation of hybrid technology in the fabrication of the aircraft part 
Ze względów technologicznych można wyróżnić podstawowe typy wytwarzanych geometrii, dla których strategia i parametry obróbki muszą być indywidualnie dostosowane (tab. 1.). Elementy pryzmatyczne to grupa elementów charakteryzujących się stałym przekrojem cech geometrycznych, pozbawionych zbieżności. Proces ich wytwarzania jest zbliżony do typowego procesu wytwarzania warstwowego, w którym są wymagane ruchy robocze w płaszczyźnie i ruch ustawczy w kierunku prostopadłym do tej płaszczyzny, związany ze zmianą wytwarzanej obecnie warstwy obiektu. Generowanie ścieżek narzędzia dla tych części jest łatwe, a parametry budowy są względnie stałe, co jest spowodowane stabilnością termiczną procesu. Części cienkościenne mają skłonność do kumulowania ciepła, co pogarsza stabilność termiczną procesu. Może się to przyczynić do powstawania porów i pogorszenia jakości powierzchni. Ponadto małe przekroje zwiększają podatność na odkształcenia spowodowane naprężeniami. Wymusza to zmniejszenie ilości dostarczanego ciepła, a w konsekwencji wydajności procesu.

Tabela 1. Podstawowe typy geometrii wytwarzanych podczas obróbki hybrydowej

Table 1. Basic types of geometries fabricated by hybrid processing

\begin{tabular}{|l|c|c|c|}
\hline \multicolumn{1}{|c|}{ Typ części } & Pryzmatyczne & Cienkościenne & Wieloosiowe \\
\hline $\begin{array}{l}\text { Kształt powierzchni } \\
\text { napawanej }\end{array}$ & planarne & planarne & $\begin{array}{c}\text { planarne/ } \\
\text { osiowosymetryczne/ } \\
\text { swobodne }\end{array}$ \\
\hline $\begin{array}{l}\text { Trudności w procesie } \\
\text { napawania }\end{array}$ & $\begin{array}{c}\text { przy znacznej } \\
\text { zmianie przekrojów }\end{array}$ & kumulacja ciepła & $\begin{array}{c}\text { utrzymanie stałej } \\
\text { normalnej }\end{array}$ \\
\hline $\begin{array}{l}\text { Stopnie swobody } \\
\text { podczas procesu }\end{array}$ & $2,5 \mathrm{D}$ & $2,5 \mathrm{D}$ & 3D/4D/5D+ \\
\hline Generowanie ścieżek & proste & proste & trudne \\
\hline
\end{tabular}

Części wieloosiowe to grupa, której wytwarzanie wymaga dodatkowych stopni swobody i realizacji na obrabiarkach o 4 osiach sterowanych lub większej ich liczbie. Do grupy tej należy zaliczyć części osiowosymetryczne, w których występują dodatkowe cechy geometryczne na powierzchni walcowej, części wielostronne wymagające obróbki indeksowanej, a także części o powierzchniach swobodnych. W tym wypadku jest wymagana realizacja procesu napawania z utrzymaniem stałej normalnej osi głowicy do powierzchni. Generowanie ścieżek narzędzia dla tego typu geometrii jest bardziej złożone i wymaga zastosowania specjalistycznego oprogramowania. Wykonywany komponent lotniczy należy do grupy części osiowosymetrycznych, a głównym wyzwaniem było wykonanie drobnych cech geometrycznych na powierzchniach obrotowych uprzednio przygotowanego półfabrykatu bazowego, a także większej geometrii na powierzchni czołowej (rys. 8.). 

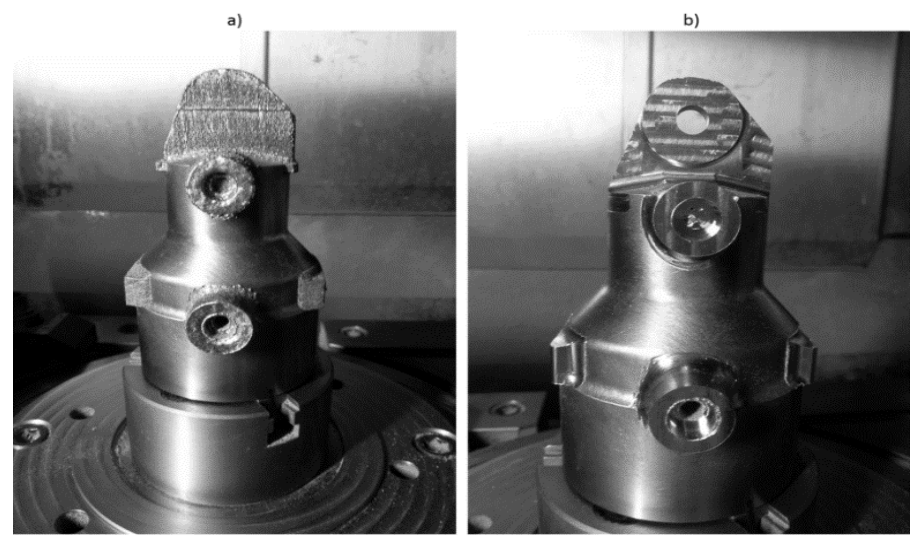

Rys. 8. Komponent lotniczy z cechami wykonanymi w technologii napawania laserowego (a) oraz po przeprowadzonej obróbce (b)

Fig. 8. Aviation component with features made in laser cladding technology (a) and after machining (b)

\section{Podsumowanie}

Napawanie laserowe to wciąż rozwojowy proces wytwarzania przyrostowego. Liczba zmiennych w tych procesach i optymalny dobór parametrów wymuszają konieczność stosowania narzędzi symulacyjnych, programów do monitorowania zjawisk termicznych, kontrolę przepływu gazów, interakcję mocy wiązki laserowej z ilością materiału, stosowanie systemów CAD/CAM zarówno dla wytwarzania przyrostowego, jak i obróbki ubytkowej oraz kontroli online aktualnego przyrostu warstw podczas procesu i ewentualne jego korygowanie. Wszystko to musi odpowiadać oczekiwanej geometrii wymiarowo-kształtowej. Sądzi się, że raz dobrane wszystkie parametry zapewnią dużą powtarzalność, tak aby można było wielokrotnie odtwarzać ten proces. Możliwości pokazują jednak ogromny potencjał tych technologii w zakresie tworzenia nowych kształtów (części) pod kątem nie tylko przemysłu lotniczego, ale również innych dziedzin wytwarzania.

\section{Podziękowania}

Badania zostały zrealizowane w ramach projektu sektorowego INNOLOT „Badania technologii przyrostowych procesów hybrydyzacji obróbki dla potrzeb rozwoju innowacyjnej produkcji lotniczej”, współfinansowanego ze środków Narodowego Centrum Badań i Rozwoju oraz Unii Europejskiej w ramach Europejskiego Funduszu Rozwoju Regionalnego w zakresie Programu Operacyjnego Innowacyjna Gospodarka Priorytet I. 


\section{Literatura}

[1] Birger E.M., Moskivitin G.V., Polyakov A.N. et al.: Industrial laser cladding: Current state and future, Welding Int., 25 (2011) 234-243.

[2] Sexton L., Lavin S., Byrne G. et al.: Laser cladding of aerospace materials, J. Mater. Proc. Technol., 122 (2002) 63-68.

[3] Jurewicz P., Rafajłowicz W., Reiner J.: Sterowanie procesem napawania laserowego bazujące na przetwarzaniu obrazów, AOW EXIT, Warszawa 2017.

[4] Baraniecki T., Chlebus E., Dziatkiewicz M. et al.: System for laser microsurfacing of metal powder, Welding Int., 30 (2016) 98-102.

[5] Pinkerton A.J.: Advances in the modeling of laser direct metal deposition, J. Laser Appl., 27 (2015) S15001.

[6] Toyserkani E., Khajepour A., Corbin S.: Laser Cladding, CRC Press 2005.

[7] Bi G., Gasser A., Wissenbach K. et al.: Characterization of the process control for the direct laser metallic powder deposition, Surface Coatings Technol., 201 (2006) 2676-2683.

[8] Ocylok S., Alexeev E., Mann S. et al.: Correlations of melt pool geometry and process parameters during laser metal deposition by coaxial process monitoring, Physics Procedia, 56 (2014) 228-238.

[9] Singh R., Kumar D., Mishra S.K. et al.: Laser cladding for Stellite 6 on stainless steel to enhance solid particle erosion and cavitation resistance, Surface Coatings Technol., 251 (2014) 87-97.

[10] Koruba P., Jurewicz P., Reiner J. i in.: Technologia ultraszybkiego napawania laserowego do nakładania powłok funkcjonalnych Stellite $6 \mathrm{w}$ branży lotniczej, Przegląd Spawalnictwa, 89 (2017) 15-19.

[11] Kathuria Y.P.: Some aspects of laser surface cladding in the turbine industry, Surface Coatings Technol., 132 (2000) 262-269.

[12] Koruba P., Wiercioch M., Reiner J.: Zastosowanie napawania laserowego do regeneracji łopatki turbiny silnika odrzutowego ze stopu ŻS6U, Młodzi Naukowcy Nauki techniczne i inżynieryjne, 6 (2016) 41-47.

[13] Kranz J., Herzog D., Emmelmann C.: Design guidelines for laser additive manufacturing of lightweight structures in TiAl6V4, J. Laser Applications, 27 (2015) S14001.

[14] Jahn S., Straube Ch., Gemse F., et al.: Influencing factors on quality of titanium components manufactured by laser melting, Conf. Proc. Fraunhofer Direct Digital Manufacturing, Berlin 2018.

[15] Zhu Z., Dhokia V.G., Nassehi A.: A review of hybrid manufactured processes - state of the art and future perspectives, Int. J. Comput. Integr. Manuf., 26 (2013) 596-615.

[16] Yamazaki T.: Development of a hybrid multi-tasking machine tool : integration of additive manufacturing technology with $\mathrm{CNC}$ machining, Procedia CIRP ISEM XVIII, 42 (2016) 81-86. 


\section{DESIGN AND APPLICATIONS ANALYSIS OF LASER CLADDING TECHNOLOGY FOR AVIATION INDUSTRY}

\section{S u m m a r y}

The laser cladding technology consists of the use of laser beam for precise deposition of a material layer with enhanced properties to the substrate. Therefore it finds special interest in the aviation industry. Appropriate preparation of the process involves performing simulation tests using two-phase flow models and laser beam interaction with material. Subsequently, the laser head movement paths are determined using dedicated CAD/CAM software. In the analysis of laser cladding technology applications for the aviation industry, the deposition of functional coatings, being an alternative to electrolytic chromium, was presented. Secondly, the repair of turbine blade tip was also analyzed. Moreover the capabilities of hybrid laser cladding technology with machining for the additive manufacturing aviation components made of titanium alloys were presented, as well as the method of temperature monitoring for the purpose of qualitative process control implementation.

Keywords: computer aided process development, multiphysics simulation, functional coating, repair of turbine blades, hybrid laser cladding

DOI: $10.7862 / \mathrm{rm} .2018 .26$

Przestano do redakcji: 24.04 .2018

Przyjęto do druku: 28.06.2018 
